\title{
Synthesis and Characterization of Electrolyte Membrane Based Biopolymer Chitosan and Fly Ash Combinations for Fuel Cell Application
}

\author{
Gugus Handika \\ Department of Chemical Enginering, \\ Post graduate \\ Technology Institute of Kalimantan \\ Balikpapan, Indonesia \\ lekpurbakung@gmail.com
}

\author{
Achmad Ilham Ghozali \\ Department of Chemical Enginering, \\ Post graduate \\ Technology Institute of Kalimantan \\ Balikpapan, Indonesia
}

Mochammad Purwanto

Department of Chemical Enginering, Post graduate

Technology Institute of Kalimantan

Balikpapan, Indonesia

\author{
Bias Hilal Saga \\ Department of Chemical Enginering, \\ Post graduate \\ Technology Institute of Kalimantan \\ Balikpapan, Indonesia
}

\begin{abstract}
A composite membrane biopolymer chitosan filled fly ash was fabricated as alternative membrane electrolyte for fuel cell application. The membrane was synthesized from chitosan from deacetylation of shrimp shells and then cross-linked with sulfonic acid network by introducing fly ash. The aim was to investigate fly ash adding to the performance of membrane. The membranes were studied by scanning electron microscopy (SEM), water uptake, methanol uptake, permeability, and proton conductivity assessment. SEM images analysis showed that the fly ash was successfully incorporated in chitosan polymer matrix. Water and methanol uptake for the composite membranes decreased with increasing fly ash loadings. The resulting membranes exhibited proton conductivities up to $6,863 \mathrm{mS} / \mathrm{cm}$. The obtained results indicated that the optimum composite membrane could be considered as a promising candidate to developed membrane electrolite for fuel cell applications.
\end{abstract}

Keywords-Chitosan, Fly Ash, Membrane, Fuel cell.

\section{INTRODUCTION}

Fuel cell is electrochemical cell that converts chemical energy into electrical energy based on redox reactions. In the application of fuel cell, a membrane acts as semipermeable layer between cathode and anode which only let hydrogen pass through and generate electricity. The specialized membrane in this application is called electrolyte membrane and well known as proton exchange membrane (PEM). The popular membrane which is widely used is perfluorosulfonic acid membrane (Nafion). Nafion works well since it has good chemical stability and excellent conductivity[1]. Nafion showed the highest conductivity 4.7 $\mathrm{x} 10-2 \mathrm{~S} / \mathrm{cm}$ under $100^{\circ} \mathrm{C}$ but high in methanol permeability at $27.6 \times 10-8 \mathrm{~cm} 2 / \mathrm{s}$. Higher the permeability, the faster hydrogen pass through membrane and reduce the efficiency. Also, Nafion is consiredably expensive. Some research found the alternative way to overcome these lackings and suggest using biopolymer based membrane, one of those is chitosan[2]

Chitosan is biopolymer which composed of $\mathrm{N}$-acetyl glucosamine residues with $1,4 \beta$ linkage[3]. It is derived from deacetylation of chitin, which is produced from shells of crustaceans. Shrimp shells contain much chitin and widely used in Indonesia as filter membrane and some medical artificial human parts. As biopolymer, chitosan is biocompatible, non-toxic, and soluble at aqueous media[4]. Chitosan is compatible for electrolyte membrane due to its structure and proton conductivity. To maintain its stability against acid solution and physically strong, a filler is used. Anorganic filler such as fly ash is needed since it has good conductivity and lower the methanol permeability[5]. In the present paper, we attempt to synthesize chitosan based electrolyte membranes which are modified with addition of fly ash composite. The properties such as proton conductivity, methanol permeability, and morphological surface are investigated systematically.

\section{EXPERIMENTAL METHODS}

\section{A. Chitosan Preparation}

First, shrimp shells is grinded into powder and then stir it at $60-70^{\circ} \mathrm{C}$ in $\mathrm{NaOH} 3,5 \%$ wt solution by the composition 1:10 (gr powder/mL $\mathrm{NaOH}$ ) for about 2 hours. The shells then filtered from the solution, washed it by demineralized water (aquadest), and dried it in oven at $100^{\circ} \mathrm{C}$ for about 4 hours. The shells then demineralized in $\mathrm{HCl}$ solution at 60$70^{\circ} \mathrm{C}$ by the composition 1:15 (gr powder/mL $\mathrm{HCl}$ ) for about 2 hours. The shells turned into chitin this time and underwent the same procedure to get dried chitin. Chitin then deacetylized in $\mathrm{NaOH} 50 \%$ wt solution by the composition 1:10 (gr powder/mL NaOH) for about 1 hour at $90-100^{\circ} \mathrm{C}$. Chitin was degraded into chitosan and lastly, same procedure is applied to get dried chitosan.

\section{B. Membrane Preparation}

The electrolyte membrane were prepared using sol-gel process. Initially, the experiments were performed by preparing various concentrations $(5 \%, 10 \%$, and $15 \%$ wt fly ash) chitosan membrane. Chitosan and fly ash were dissolved in 75 grams of acetic acid $2 \% \mathrm{v} / \mathrm{v}$ at $80^{\circ} \mathrm{C}$ until the solution formed gel. The solution was placed to cool in petri dish for about 2 days. After the thin film were formed, the 
membrane then poured with $\mathrm{NaOH}$ solution to faster the peeling. The membrane then washed to remove remaining solvent and re-immersed with $\mathrm{H}_{2} \mathrm{SO}_{4} 1 \mathrm{M}$ for about 24 hours. The resultant membrane then washed and dried at room temperature.

\section{Chitin and Chitosan Characterization}

Membrane characterization was attempted by the use of instrumental analysis. Fourier Transport Infra Red (FTIR) Spectroscopy was used to characterize functional group of chitin and chitosan. The sample was directly hit by electromagnetic radiation to get the absorbance and then correlate between the absorbance and the functional group.

The main parameter of chitin deacetylation was the disapperance of acetyl group. The amount of liberated acetyl groups would determine degree of deacetylation (DD) which indicated the purity of chitosan. The higher the DD, the purer chitosan would be which lead the better membrane synhesize. A good DD of chitosan for synthesizing membranes were in range $70 \%-100 \%$. DD was determined based on base line method. This method was based on the infrared absorbtion value of wavelength of $1655 \mathrm{~cm}^{-1}$ and $3450 \mathrm{~cm}^{-1}$. The equation were shown below:

$$
\mathrm{DD}=\left[1-\left(\mathrm{A}_{1655} / \mathrm{A}_{3450}\right) *(1 / 1.33)\right] * 100 \%
$$

Where : $A_{1655}=$ absorbance value of $1655 \mathrm{~cm}^{-1}$ (amide group absorbance)

$\mathrm{A}_{3450}=$ absorbance value of $3450 \mathrm{~cm}^{-1}$ (hydroxil group absorbance)

$1.33=$ constant of perfect deacetylation $(100 \%)$

\section{Water and Methanol Uptake Measurements}

Water uptake and methanol uptake were determined by measuring the wet membrane and dried membrane. First, the membranes were dried at $60^{\circ} \mathrm{C}$ for 20 minutes and then weighed. The membranes were immersed in water or methanol for 24 hours to get maximum hydration. The surface of membrane then wiped with tissue and the weighed again. The formula for water and methanol uptake are shown below:

$$
\text { Uptake }(\%)=((\text { Wwet }- \text { Wdry }) / \text { Wdry }) \times 100 \%
$$

Where Wwet and Wdry are the mass of membrane before and after immersion (gram).

\section{E. Methanol Permeability Measurements}

Methanol permeability is one of parameter that evaluates membrane performance. To determine mthanol permeability, two diffusion cell compartments is needed. Membranes were cut into $2 \times 2 \mathrm{~cm}$ in rectangular size and then placed it in between the compartments. Compartment A filled with $1 \mathrm{M}$ methanol solution and compartment $\mathrm{B}$ filled with water. Methanol solution was sampled every 30 minutes for about 2.5 hours. Methanol concentration can be determined by using piknometer and corrected it with calibration curve. The sampled concentrations were regressed to get its slope. Methanol permeability formula as follows :

$$
\mathrm{P}=\left[\Delta \mathrm{C}_{\mathrm{B}} / \Delta \mathrm{t}\right] *\left[\mathrm{~L} * \mathrm{~V}_{\mathrm{B}} /\left(\mathrm{A}^{*} \mathrm{C}_{\mathrm{A}}\right)\right]
$$

Where: $\mathrm{P}=$ methanol permeability $\left(\mathrm{cm}^{2} / \mathrm{s}\right)$

$\Delta \mathrm{C}_{\mathrm{B}} / \Delta \mathrm{t}=$ slope determined by function of time (mol/L.s)

$\mathrm{L}=$ membrane thickness $(\mathrm{cm})$

$\mathrm{V}_{\mathrm{B}} \quad=$ volume of water in compartment $\left(\mathrm{cm}^{3}\right)$

A $=$ membrane surface area $\left(\mathrm{cm}^{2}\right)$

$\mathrm{C}_{\mathrm{A}}=$ methanol concentration in compartment $(\mathrm{mol} / \mathrm{L})$

\section{F. Ion Exchange Capacity Measurements}

The miliohmmeter was used for calculating the bulk resistance of the membrane. The bulk resistance values would simulated in z-view application to get the approximate $\mathrm{R}$ values. This $\mathrm{R}$ value was used to determine conductivity by the following equation:

$$
\text { Conductivity }(\delta)=\left[\mathrm{d} /\left(\mathrm{R}^{*} \mathrm{~A}\right)\right]
$$

Where $\mathrm{R}$ is resitance (ohm), $\mathrm{d}$ and A are thickness and area of membrane tested, respectively.

\section{G. Membrane Morphology Examinations}

Scanning Electron Microscopy (SEM) was used to observe the membrane's morphology by multiple magnifications. The magnification is ranging from 1000x to 10000x.

\section{RESULTS AND DISCUSSION}

\section{A. Membrane Structure and Functional Group Study}

FTIR assessments were to determine the group functionality of chitin and chitosan. The results were shown in the diagram below:

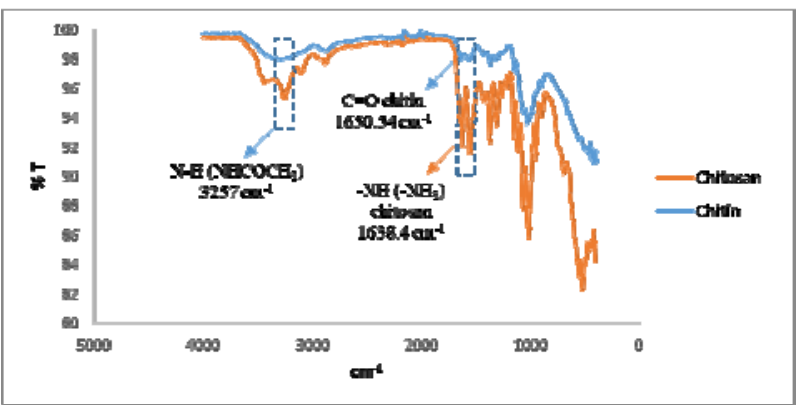

Fig 1. Chitin and Chitosan Infrared Spectroscopy Wavelengths

Numerous wavelengths were caught in FTIR spectrum. Chitin wavelengths were in about $3400-3500 \mathrm{~cm}^{-1}$ which indicated the $\mathrm{OH}$ group existed. Another absorption were in $3257.14 \mathrm{~cm}^{-1}$ which came from $-\mathrm{NH}$ groups of amide and supported with $1620.69 \mathrm{~cm}^{-1}$ wavelength. $\mathrm{CH}_{3}$ groups were found in wavelength $2878.36 \mathrm{~cm}^{-1}$. CN groups were on the peak at wavelength of $1308.35 \mathrm{~cm}^{-1} . \mathrm{C}=\mathrm{O}$ groups were in a range of $1700-1650 \mathrm{~cm}^{-1}$. C-H groups were shown on the peak of $1376.56 \mathrm{~cm}^{-1}$ and $1416.48 \mathrm{~cm}^{-1}$ wavelength. C-O groups were seen on the wavelength of $1070.38 \mathrm{~cm}^{-1}$. Another characteristic from chitin was C-O-C groups on the wavelength of $1203.72 \mathrm{~cm}^{-1}$.

There were enough proof that chitosan were formed by chitin deacetilation. Chitosan wavelength were shown at $3282.5 \mathrm{~cm}^{-1}$. This absorption shown there were bending of 
$\mathrm{OH}$ and NH chains. This could be happened by intersection between $\mathrm{OH}$ and $\mathrm{NH}$ from amine group of chitosan. Moreover, the disapperance of $\mathrm{C}=\mathrm{O}$ from amide group were shown no wavelength. A comparative study were shown in the table below:

Table 1. Comparative Analysis of Structure and Funcional Groups For Chitin and Chitosan

\begin{tabular}{|c|l|l|l|}
\hline \multirow{2}{*}{ Num. } & \multirow{2}{*}{ Vibration } & \multicolumn{2}{c|}{ Wavelength $\left(\mathrm{cm}^{-1}\right)$} \\
\cline { 3 - 4 } & & \multicolumn{1}{|c|}{ Kitin } & \multicolumn{1}{|c|}{ Kitosan } \\
\hline 1 & O-H & 3480 & 3282.85 \\
\hline 2 & \multirow{2}{*}{ N-H $\left(-\mathrm{NHCOCH}_{3}\right)$} & $\begin{array}{l}3257.14 ; \\
1620.69\end{array}$ & - \\
\hline 3 & $-\mathrm{CH} 3$ & 2878.36 & 2850 \\
\hline 4 & $-\mathrm{C}-\mathrm{N}$ & 1308.35 & 1340 \\
\hline 5 & $-\mathrm{C}-\mathrm{H}$ & $1376.56 ;$ & 1375.39 \\
& & 1416.48 & \\
\hline 6 & $\mathrm{C}=\mathrm{O}$ & 1650 & - \\
\hline 7 & NH (-NH3) & - & 1638.54 \\
\hline 8 & $-\mathrm{C}-\mathrm{O}$ & 1070,38 & $1149.17 ;$ \\
\hline
\end{tabular}

From these results, chitosan was succesfully formed by deacetylation of chitin and the degree of deacetylation chitosan was confirmed of $75.34 \%$. This result indicated that chitin was partially deacetylated into chitosan and it was fair enough to make a good membrane.

\section{B. Water Uptake and Methanol Uptake Study}

As can be seen in figure 2 , the \% uptake for both water and methanol increase by the addition of fly ash content. This phenomenon is primarily caused by the role of fly ash that may create selective voids in the interfacial area. There were large uptake for water than methanol. This could happen due to hydrophilic properties that fly ash have could take up much water solution instead of methanol ${ }^{[6]}$. Moreover, there were many possibilities for the membrane able to absorb solutions such as porosity, cristalinity, and surface area of membrane which were explained in another study. The presence of water is needed to help the proton crossing to cathode. The higher the water content would increase the chance of proton crossing and also increase proton conductivity. Methanol uptake was proportional to water uptake which can absorb as much as hydrogen ${ }^{[7]}$. The result were consecutively shown $63.52 \%, 78.46 \%, 80.39 \%$ for water uptake and $41.25 \%, 45.87 \%, 56.06 \%$ for methanol uptake.

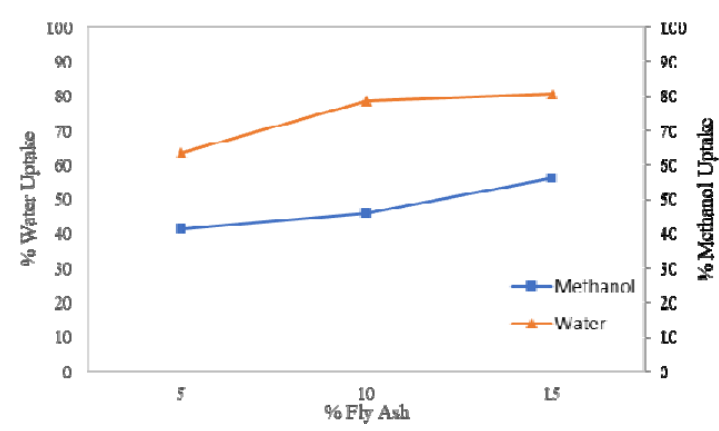

Fig.2 . Uptake for Various Fly Ash Addition at $25^{\circ} \mathrm{C}$

\section{Methanol Permeability Study}

Methanol permeability tests showed a comparative result which shown in the table below:

Table 2. Methanol Permeability Test Results of Various Membranes

\begin{tabular}{|c|c|}
\hline \multicolumn{1}{|c|}{ Membrane } & $\begin{array}{c}\text { Methanol } \\
\text { Permeability } \\
\left(\mathbf{x 1 0}^{-6} \mathbf{c m}^{\mathbf{2}} / \mathbf{s}\right)\end{array}$ \\
\hline Chitosan / Fly Ash 5\% & 8,93 \\
\hline Chitosan / Fly Ash 10\% & 6,30 \\
\hline Chitosan / Fly Ash 15\% & 2,85 \\
\hline
\end{tabular}

From these results, the membranes still have high methanol permeability due to their morphological structure which were not good enough. The blending between membrane and filler was not uniformly so there was still methanol passed through. From table 2, the permeability decrease as more fly ash were added. It has been suggested that, this phenomenon is might due to the existence of filler which increases the tightness of composite membrane so it can suppress the methanol movement ${ }^{[8]}$. The addition of fly ash would make the membrane more difficult for solution to breakthrough as the grains made formation and covered the pore. Also, the lacks interaction between ionic clusters and methanol could affect the permeability due to larger interfacial free volume ${ }^{[9]}$. The best result shown in the table is membrane with $15 \%$ fly ash addition.

\section{Ion Exchange Capacity Study}

Ion exchange capacity test was to determine membrane conductivity. Conductivity is an important value for membrane to transfer proton in fuel cell application. Conductivity data were shown in table 3.

Table 3. Membrane Conducivity Test Results of Various Membranes

\begin{tabular}{|c|c|}
\hline Membrane & $\begin{array}{c}\text { Membrane } \\
\text { Conductivity } \\
\left(\mathbf{x 1 0}^{-3} \text { S/cm) }\right.\end{array}$ \\
\hline Chitosan / Fly Ash 5\% & 6.693 \\
\hline Chitosan / Fly Ash 10\% & 6.863 \\
\hline Chitosan / Fly Ash 15\% & 0,485 \\
\hline
\end{tabular}

Addition of fly ash would increase small amount of conductivity. Higher concetration of fly ash would increase the conductivity, and also it depends on the distribution of fly ash in membrane matrix. The distribution was initiated by crosslinking membrane matrix with $\mathrm{H}_{2} \mathrm{SO}_{4}$ so fly ash particles easily integrated in matrix. But take notice that adding too much fly ash would decrease the conductivity. The grains were aggregated in the matrix and blocked the solution $^{[10]}$. The best conductivity shown was membrane 
with $10 \%$ fly ash because of its distribution and methanol permeability.

\section{E. Morphological Surface Study}

Scanning Electron Microscopy (SEM) was used to examine the morphological surface. The results were shown in figure 3.

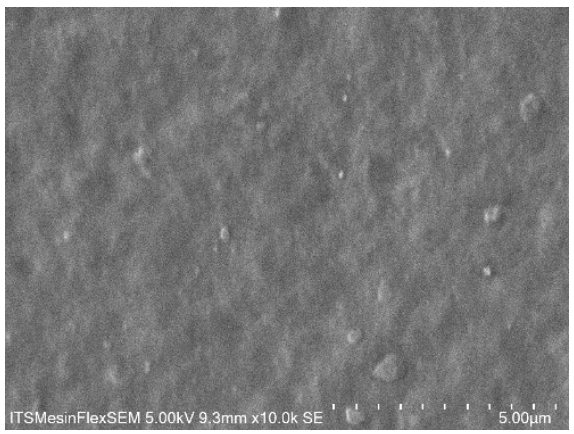

(a)

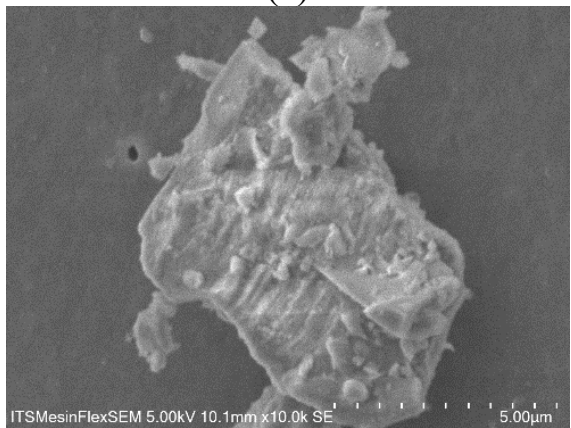

(b)

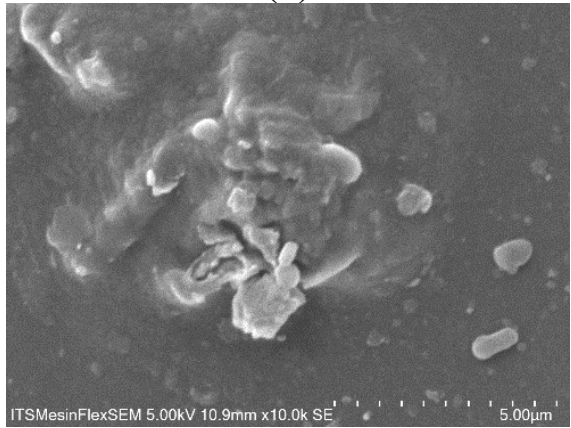

(c)

Fig 3. Morphological Surface of Membrane with 10.000x Magnification. (a) 5\% Fly Ash Membrane, (b) 10\% Fly Ash Membrane, (c) 15\% Fly Ash Membrane.

From figure $3 \mathrm{a}, 5 \%$ fly ash membrane showed that fly ash grains were distributed uniformly and the pore sizes were the same. In figure $2 \mathrm{~b}$ and $2 \mathrm{c}$, addition of fly ash $10 \%$ and $15 \%$ affected the morphological structure of membrane. It were shown the bulk formation of grains in particular places of matrix and there were bigger pores among them. Addition of fly ash would generated bigger pore density which the amount of pores in the membrane's surface and reduce the pore size but increasing the chance the grains would aggregate rather than mixing uniformly. Higher pore density means the membrane could take up fuel as much as possible which explained the methanol permeability ${ }^{[10]}$.

\section{CONCLUSIONS}

Chitosan / Fly ash membrane for fuel cell application was prepared with addition of fly ash. Membrane characterization including water uptake, methanol uptake, methanol permeability, membrane conductivity, and morphological surface have also been performed. It has been shown that the resultant membranes were good in water uptake which are in range of $60 \%-80 \%$ and methanol uptake in range of $40 \%$ $60 \%$. The methanol permeability result showed that the maximum value of $2.85 \times 10^{-6} \mathrm{~cm}^{2} / \mathrm{s}$ is reached with $15 \%$ fly ash membrane. The membrane conductivity reached maximum conductivity value of $6.863 \times 10^{-3} \mathrm{~S} / \mathrm{cm}$ with $10 \%$ fly ash membrane. Based on the results, it can be concluded that Chitosan/Fly ash composite membrane has a high potential to be electrolyte membrane for fuel cell application.

\section{ACKNOWLEDGEMENT}

The authors gratefully acknowledge the Ministry of Research, Technology, and Higher Education, Indonesia (KEMENRISTEKDIKTI), the Republic of Indonesia for the financial supports of this research.

\section{REFERENCES}

[1] Wu, H., Zheng, B., Zheng, X., Wang, J., Yuan, W., Jiang, Z. (2007) "Surface-modified Y zeolite-filled chitosan membrane for direct methanol fuel cell", Jurnal of Power Sources, Vol. 173, pp. 842-852

[2] Smitha, B., Devi, A.D. and Sridhar, S. Proton-Conducting Composite Membrane of Chitosan and Sulfonated Polysulfone for Fuel Cell Application, International Journal of Hydrogen Energy, 2008, pp. $4138-4146$

[3] Rinaudo, M. (2006). Chitin and chitosan: Properties and applications. Progress in Polymer Science, 31(7), 603-632.

[4] Muzzarelli, R. A. A. 1983, Chitin And Its Derivatives: New Trends Of Applied Research, Carbohydrate Polymer,vol.1, no.3, pp. 53-75.

[5] Ari Vitri Wulandari, Ella Kusumastuti, Triastuti Sulistyaningsih. Pengaruh Penambahan Abu Layang Termodifikasi terhadap Karakteristik Membran Elektrolit Berbahan Dasar Kitosan. Indonesian Journal of Chemical Science 6 (2), 2017, pp. 105-107.

[6] Bahavian, P.P., Sainul, A.K., Kannan, R., Sivakumar, M., Wang F.M., Rajashabala, S., Velraj, G. Improvement of Proton Conductivity Nanocomposite Polyvinil Alcohol (PVA)/Chitosan (Cs) Blend Membranes,India : Royal Society of Chemistry, 2014.

[7] Piluharto B, Suendo V, \& Ciptati T. Radiman, CL. Strong Correlation Between Membrane Effective Fixed Charge And Proton Conductivity In The Sulfonated Polysulfone CationExchange Membranes, Ionics, 2011, 17:229-238

[8] Mochammad Purwanto, Lukman Atmaja, Mohamad Azuwa Mohamed, M. T. Salleh, Juhana Jaafar, A. F. Ismail, Mardi santoso, and Nurul Widiastuti. Biopolymer-based electrolyte membranes from chitosan incorporated with montmorillonite-crosslinked GPTMS for direct methanol fuel cells. RSC Advances, 2016, 6, 2314 - 2322

[9] W. Yuan, H. Wu, B. Zheng, X. Zheng, Z. Jiang, X. Hao, B. Wang, Sorbitol-plasticized chitosan/zeolite hybrid membrane for direct methanol fuel cell, J. Power Sources 172, 2007, pp. 604-612.

[10] H. Li, Y.M. Chen, X.T. Ma, J.L. Shi, B.K. Zhu, L.P. Zhu, Gel polymer electrolytes based on active PVDF separator for lithium ion battery. I: Preparation and property of PVDF / poly (dimethylsiloxane) blending membrane, J. Membr.Sci. 379, 2011, pp. 397-402.

[11] M. Osinska, M. Walkowiak, A. Zalewska, T. Jesionowski, Study of the role of ceramic filler in composite gel electrolytes based on microporous polymer membranes, J. Membr. Sci. 326, 2009, pp. 582588. 